\begin{tabular}{lc}
\hline \hline UAD & Jurnal Psikologi Terapan dan Pendidikan \\
Vol. 2, No. 1, Mei 2020, ph. 48-54 \\
ISSN $2715-2456$
\end{tabular}

\title{
Komik edukasi sebagai media layanan bimbingan dan konseling
}

\author{
Taufik Agung Pranowo ${ }^{\mathrm{a}, 1^{*}}$ \\ aBimbingan dan Konseling, Universitas PGRI, Yogyakarta \\ *1taufikagung@upy.ac.id \\ Correspondent Author
}

KAT A KUNCI

ABSTRAK

bimbingan dan konseling; media bimbingan konseling; komik edukasi

KEYWORDS

educational comics; guidance and counseling. guidance and counseling media
Media pendidikan merupakan unsur yang penting dalam proses pendidikan khususnya proses bimbingan dan konseling. Media bimbingan dan konseling dapat berfungsi untuk memperlancar proses bimbingan dan konseling, dan lebih mudah diterima oleh siswa untuk memahami masalah yang dialami. Sementara komik tidak dapat terlepas fungsinya sebagai alat komunikasi untuk menyampaikan suatu maksud atau tendensi tertentu kepada pembacanya. Komik merupakan alat yang mempunyai fungsi menyampaikan pesan. Sebagai sebuah media, pesan yang disampaikan lewat komik biasanya jelas, runtut, dan menyenangkan. Oleh karena itu, penelitian ini ingin mengkaji peran komik sebagai media edukasi dalam layanan bimbingan konseling. Metode yang digunakan pada penelitian ini adalah studi literatur. Adapun pemilihan literatur disesuaikan dengan topik yang dikaji yaitu terkait dengan komik sebagai media dalam melakukan edukasi di layanan bimbingan dan konseling. Berdasarkan hasil penelitian maka dapat disimpulkan bahwa media komik berpotensi untuk menjadi sumber belajar, khususnya dalam proses pemberian layanan bimbingan dan konseling di sekolah. Peranan pokok dari komik edukasi adalah kemampuannya dalam menciptakan minat para peserta didik. Melalui bimbingan guru, komik dapat berfungsi sebagai jembatan untuk menumbuhkan minat peserta didik terhadap pemberian bimbingan yang dilakukan.

\section{Educational comics as guidance and counseling service media}

Educational media is an important element in the educational process, especially the process of guidance and counseling. Guidance and counseling media can function to facilitate the guidance and counseling process, and be more easily accepted by students to understand the problems they are experiencing. Meanwhile, comics cannot be separated from their function as a means of communication to convey a certain intention or tendency to their readers. Comics are a tool that has the function of conveying messages. As a medium, messages conveyed through comics are usually clear, coherent, and fun. Therefore, this study aims to examine the role of comics as an educational medium in counseling guidance services. The method used in this research is literature study. The selection of literature is adjusted to the topic being studied, namely related to comics as a medium in conducting education in guidance and counseling services. Based on the research results, it can be concluded that comic media has the potential to be a source of learning, especially in the process of providing guidance and counseling services in schools. The main role of educational comics is their ability 
to create interest in students. Through teacher guidance, comics can serve as a bridge to foster students' interest in providing guidance.

This is an open-access article under the CC-BY-SA license.

\section{Pendahuluan}

Bimbingan dan Konseling sebagai suatu proses pemberian bantuan kepada individu (siswa), dilaksanakan melalui berbagai macam layanan dan layanan tersebut dapat dilakukan secara langsung dan tidak langsung. Konseling merupakan kegiatan profesional dimana dalam pelayanan bahwa ahli tidak hanya sekadar menerapkan seperangkat prosedur tetap, melainkan terus berpikir dengan mengerahkan kemampuan yang dimiliki dan dikuasai untuk melaksanakan layanan konseling (Radjah, 2016). Pemberian layanan bimbingan dan konseling dapat dilakukan dengan cara-cara yang lebih menarik, interaktif, dan tidak terbatas tempat, tetapi juga tetap memperhatikan azas-azas dan kode etik dalam bimbingan dan konseling. Bimbingan dan konseling merupakan suatu kegiatan yang melibatkan seorang guru BK (Bimbingan Konseling) atau konselor dalam upaya memandirikan siswa. Pada proses bimbingan dan konseling, guru BK memfasilitasi siswa untuk dapat menyadari, mengksplorasi permasalahan yang dihadapi serta kemungkinan-kemungkinan permasalahan yang terbuka.

Bimbingan dan konseling merupakan sebuah sistem karena di dalamnya mengandung beberapa komponen-komponen yang saling berkaitan untuk mencapai suatu tujuan yang telah ditetapkan. Komponen-komponen tersebut meliputi masalah, tujuan, teknik, media dan evaluasi. Masing-masing komponen tersebut saling berkaitan erat dan merupakan satu kesatuan. Selanjutnya, proses bimbingan dan konseling merupakan proses komunikasi, artinya di dalam bimbingan dan konseling terjadi proses penyampaian pesan dari seseorang (sumber pesan) kepada seseorang atau sekelompok orang (penerima pesan). Sementara, sebagai bentuk komunikasi maka layanan bimbingan dan konseling manapun sangat membutuhkan peran media untuk lebih meningkatkan efektivitas pencapaian tujuan (Basri, 2010). Dengan demikian media merupakan bagian dari proses komunikasi yang penting dalam pemberian layananan bimbingan dan konseling.

Salah satu media pendidikan yang dapat digunakan, dimanfaatkan, dan mudah dijangkau diantaranya adalah media berbasis cetakan. Media pendidikan berbasis cetakan merupakan salah satu alat yang dapat membantu guru Bimbingan dan Konseling guna menarik minat dan perhatian siswa dalam belajar. Adapun salah satu media berbasis cetakan yang dapat digunakan adalah komik. Komik merupakan salah satu media yang menarik dan memang isinya harus disesuaikan dengan taraf perkembangan siswa. Sesuai dengan yang disampaikan Beaulieu (2004) bahwa gambar memiliki kemampuan untuk menyampaikan banyak informasi dengan ringkas dan dapat lebih mudah diingat dalam jangka panjang.

Komik dapat dikatakan menarik karena di dalamnya terdapat unsur-unsur yang menyenangkan, menggairahkan, mudah dibaca dan dapat merangsang imajinasi anak. Hal ini mengingat kelebihan komik sebagai media grafis yang memiliki karakteristik sederhana, jelas, mudah dan bersifat personal. Hurlock (2010) menjelaskan bahwa terlepas dari tingkat kecerdasan, hampir semua anak menyenangi komik, baik yang bersifat lelucon atau petualangan.Sehubungan dengan hal tersebut maka komik dapat dikembangan oleh guru BK sebagai sarana pelaksanaan layanan bimbingan dan konseling di sekolah. Pengembangan komik menjadi media bimbingan dan konseling merupakan bagian dari proses bimbingan dan konseling, dimana guru BK mencoba memahami beberapa hal tentang masalah siswa dan perkembangan yang dialami siswa dengan memberikan pelayanan dengan memanfaatkan 
media yang menarik untuk anak.

Namun demikian, sejauh ini tidak semua komik yang beredar di pasaran dapat membawa dampak positif. Bahkan sebagian besar komik yang beredar di pasaran terkadang dapat dikatakan jauh dari unsur-unsur pendidikan. Pada umumnya komik yang beredar di pasaran hanya komik yang menggambarkan percintaan, duel dan lelucon yang tidak tentu arah. Dengan demikian, tidak dapat dipungkiri sebagian masyarakat pada akhirnya memberikan label negatif pada komik tertentu, karena dapat menstimulasi perilaku negatif saat dibaca oleh anak-anak. Oleh karena itu, membenahi komik, khususnhya pada bagian konten dianggap penting agar dapat dimanfaatkan dalam dunia pendidikan pendidikan, khususnya guru BK yaitu sebagai media menyampaikan bimbingan, karena bimbingan merupakan bagian dari subsistem pendidikan.

Pada kegiatan bimbingan dan konseling, komik edukasi sebagai media bimbingan dan konseling diantaranya dapat digunakan untuk membangkitkan motivasi belajar siswa, karena penggunaan media dapat memberikan stimulasi belajar terutama rasa ingin tahu siswa terhadap sesuatu yang akan dipelajarinya. Seperti penelitian yang dilakukan Cho dan Lawrence (2012) tentang "instructional comics can stimulate student interest and motivation, and reduce anxiety". Hasil penelitian tersebut menjelaskan bahwa komik edukasi dapat dimanfaatkan untuk merangsang siswa dalam belajar. Oleh karena itu, adapun tujuan penelitian ini adalah menjelaskan bagaimana komik berperan sebagai media komunikasi dalam layanan bimbingan konseling. Adapun kontribusi dengan dilakukannya penelitian ini adalah agar guru di bidang layanan bimbingan dan konseling dapat memberikan layanan menjadi lebih menarik melalui berbagai metode, salah satunya dengan menggunakan komik sebagai cara melakukan edukasi.

\section{Metode}

Penelitian ini merupakan penelitian studi literatur dengan menelaah beberapa jurnal dan literatur terkait komik edukasi yang dikaitkan sebagai media dalam layanan bimbingan dan konseling. Hasil dari berbagai telaah literatur ini digunakan untuk mengetahui bagaimana komik berperan dalam layanan bimbingan dan konseling.

\section{Media Bimbingan dan Konseling}

Bimbingan dan konseling merupakan bagian penting dalam proses pendidikan. Pendidikan yang bermutu adalah pendidikan yang mengintegrasikan tiga bidang kegiatan utamanya secara sinergis, yaitu bidang administratif dan kepemimpinan, bidang instruksional dan kurikuler, dan bidang bimbingan dan konseling (Yusuf \& Nurihsan, 2010). Berkaitan dengan hal tersebut maka semua hal yang berhubungan dengan pendidikan, padadasarnya harus memiliki unsur bimbingan dan konseling, termasuk dengan pengembangan media bimbingan dan konseling.

Pengertian media dalam dunia pendidikan menurut Arsyad (2011) hampir sama dengan pengertian media pada umumnya, tetapi lebih difokuskan pada proses belajar mengajar, dan secara khusus cenderung diartikan sebgai alat-alat grafis, photografis, atau elektronis untuk menangkap, memproses dan menyusun kembali informasi visual verbal. Media pendidikan menurut Gagne (dalam Sardiman dkk, 2000) adalah berbagai jenis komponen dalam lingkungan siswa yang dapat merangsang siswa untuk belajar. Artinya, media pendidikan adalah peralatan yang dapat mendukung perkembangan fisik, motorik, sosial, emosi, kognitif, kreatifitas dan bahasa anak. Asyhar (2012) menyatakan bahwa media pendidikan merupakan segala sesuatu yang dapat menyampaikan atau menyalurkan pesan dari suatu sumber secara terencana, sehingga terjadi lingkungan belajar yang kondusif dimana penerimannya dapat melakukan proses belajar secara efisien dan efektif.

Asyhar (2012) menyatakan bahwa media pendidikan memiliki beberapa fungsi antara lain: 
1. Fungsi atensi, media pendidikan dapat mengambil perhatian siswa terhadap materi yang dibahas.

2. Fungsi afektif, media pendidikan dapat menggugah perasaan, emosi dan tingkat penerimaan atau penolakan siswa terhadap materi yang diberikan.

3. Fungsi kognitif, media pendidikan memberikan pengetahuan dan pemahaman baru kepada siswa tentang sesuatu hal.

4. Fungsi psikomotorik, media pendidikan dapat membangkitkan ketrampilan yang bersifat fisik atau tampilan pada seseorang.

5. Fungsi imajinatif, media pendidikan dapat menimbulkan imajinasi pada siswa berupa objek-objek baru atau menimbulkan kreasi sebagai rencana masa mendatang atau juga dapat mengambil bentuk fantasi yang didominasi kuat oleh pikiran-pikiran autistik.

6. Fungsi motivasi, media pendidikan dapat membangkitkan motivasi belajar siswa, sebab penggunaan media pendidikan menjadi lebih menarik dan memusatkan perhatian siswa.

7. Fungsi sosio kultural, media pendidikan dapat mengatasi hambatan sosiokultural antar siswa.

Hal yang sama juga diungkapkan Wenda (2009), bahwa media pendidikan khususnya media berbasis cetakan memiliki lima fungsi, antara lain:

1. Fungsi atensi, yakni untuk mengarahkan konsentrasi kepada isi pelajaran yang ditampilkan.

2. Fungsi motivasi, yakni untuk mendorong lebih giat belajar, karena siswa memiliki motivasi dengan memperhatikan media saat itu akan memungkinkan belajar mandiri sesuai dengan bakatnya.

3. Fungsi afeksi, yakni untuk menggugah emosi dan sikap.

4. Fungsi kompensatori, yakni untuk memperhatikan yang lemah dalam menerima dan memahami pelajaran yang disajikan secara teks dan verbal.

5. Fungsi psikomotorik, yakni untuk menggerakkan dalam melakukan suatu kegiatan.

Berbicara tentang media pendidikan, dalam lingkup bimbingan dan konseling bahwa media dianggap sebagai sarana/ perantara atau pengantar ketika guru BK (konselor) melaksanakan layanan bimbingan dan konseling khususnya kepada konseli (siswa). Media dalam bimbingan dan konseling digunakan sebagai strategi implementasi program layanan, khususnya pelayanan dasar yang dilakukan dengan layanan informasi secara tidak langsung. Layanan informasi merupakan pemberian informasi tentang berbagai hal yang dipandang bermanfaat bagi siswa melalui komunikasi langsung maupun tidak langsung melalui media cetak maupun elektronik (Departemen Pendidikan Nasional, 2008).

Media pendidikan merupakan unsur yang penting dalam proses pendidikan khususnya proses bimbingan dan konseling. Dengana adanya media, bahwa bimbingan dan konseling diasumsikan dapat berfungsi lebih lancar dalam proses pelaksanaannya. Begitupula, bahwa media bimbingan dan konseling dapat lebih mudah dan cepat diterima oleh siswa untuk memahami masalah yang dialami melalui bahan yang disajikan. Selain itu, media bimbingan dan konseling juga dapat meningkatkan kualitas layanan bimbingan dan konseling.

\section{Komik Edukasi}

Komik merupakan salah satu bentuk media pembelajaran berbasis cetakan dengan jenis lembaran lepas. Komik sebagai suatu bentuk kartun yang mengungkap karakter dan memerankan suatu cerita dalam urutan yang erat dihubungkan dengan gambar, dan dirancang untuk memberikan hiburan atau menyampaikan informasi kepada pembacanya. Sesuai dengan yang disampaikan Daryanto (2013) bahwa komik dapat didefinisikan sebagai bentuk kartun yang mengungkapkan karakter dan menerapkan suatu cerita dalam urutan yang erat hubungannya dengan gambar dan dirancang untuk memberikan hiburan kepada para pembaca.

Komik edukasi merupakan cerita bergambar yang ditata sesuai dengan tujuan. Pada umumnya komik mudah dicerna dan digunakan sesuai dengan kebutuhan, yaitu sebagai 
media bimbingan, pembelajaran atau pertolongan untuk mewujudkan suasana belajar dan pembelajaran. Tujuannya adalah agar peserta didik dapat berkembang secara mandiri dan optimal. Menurut Boneff (2008), komik yang berkembang dalam industri komik saat ini dapat dibagi menjadi dua jenis yaitu

1. Comic strip atau newspaper strip adalah jenis komik yang terbit harian atau mingguan, dan terdiri dari susunan beberapa panel saja. Di Indonesia komik strip tercatat sebagai komik yang pertama kali terbit, tepatnya pada tahun 1930 yaitu komik humor yang menceritakan beberapa petualangan tokoh jenaka karya Kho wang Gie di surat kabar Sin Po, sebuah media komunikasi China peranakan yang berbahasa Melayu. Comic strip adalah suatu bentuk komik yang dimuat dalam bentuk jalur dalam mingguan ataupun harian secara bersambung atau berseri.

2. Comic books adalah sebuah jenis komik yang menunjuk kepada kemasan komik yang berbentuk buku, berisi satu cerita dan biasanya memiliki halaman-halaman yang disediakan menjadi rubrik korespondensi, informasi komersial (seperti agen penjualan komik beserta merchandise-nya) dan informasi (review) komik edisi yang lain, juga pengenalan studio atau komikus. Comic books adalah suatu bentuk komik yang diterbitkan secara terberkas menjadi suatu buku.

Penggunaan komik yang dipadukan dengan bimbingan dan metode mengajar guru dapat menjadikan komik sebagai media bimbingan yang efektif. Kelebihan komik antara lain adalah sederhana, jelas, mudah, dan bersifat personal. Pemakaiannya yang luas dengan ilustrasi berwarna, alur cerita yang ringkas, dan perwatakan orang yang realistis dapat menarik semua siswa dari berbagai usia.

\section{Media Bimbingan dan Konseling Menggunakan Komik Edukasi}

Komik tidak dapat terlepas fungsinya sebagai alat komunikasi yang tentu saja harus menyampaikan suatu maksud atau tendensi tertentu kepada pembacanya. Komik merupakan alat yang mempunyai fungsi menyampaikan pesan. Sebagai sebuah media, pesan yang disampaikan lewat komik biasanya jelas, runtut, dan menyenangkan. Oleh karena itu, media komik berpotensi untuk menjadi sumber belajar. Dengan demikian, unsur-unsur penting yang berkaitan dengan komik harus dimasukkan di dalam komik edukasi agar hasil komik edukasi dapat menjadi jelas, runtut, mudah dipahami dan menyenangkan dalam proses edukasi.

Menurut Bruner (dalam Arsyad, 2011), ada tiga tingkatan utama modus belajar yaitu pengalaman langsung (enactive), pengalaman pictorial/gambar (iconic), dan pengalaman abstrak (symbolic). Levie and Levie (dalam Sukiman, 2012) memberikan hasil penelitian tentang belajar melalui stimulus gambar dan stimulus kata atau visual verbal menyimpulkan bahwa stimulus visual membahkan hasil belajar yang lebih baik, di pihak lain stimulus verbal memberikan hasil belajar yang lebih apabila pembelajaran tersebut melibatkan ingatan yang berurut-urutan.

Pada pemilihan media bimbingan dan konseling harus mempertimbangkan beberapa hal, misalnya karakteristik siswa. Pemilihan media didasarkan pada hasil analisis yang tajam terhadap berbagai faktor seperti tujuan, siswa, metode pembelajaran dan kemampuan tekhnologi yang tersedia. Menurut Asyhar (2012), kriteria media pendidikan yang baik perlu memperhatikan proses pemilihan media antara lain, jelas dan rapi, bersih dan menarik, sesuai dengan sasaran, relevan dengan topik yang diajarkan, sesuai dengan tujuan pembelajaran, praktis, luwes dan tahan, berkualitas baik, ukurannya sesuai dengan lingkungan belajar.

Komik dapat dikembangan sebagai media bimbingan dan konseling untuk memberikan layanan bimbingan dan konseling khususnya layanan bidang akademik atau belajar. Menurut Hurlock (2010), bahwa terlepas dari tingkat kecerdasan, hampir semua anak menyenangi komik, baik yang berisi fat lelucon atau petualangan. Buku komik dapat dikatakan menarik karena di dalamnya terdapat unsur-unsur yang menyenangkan, menggairahkan, mudah 
dibaca dan dapat merangsang imajinasi anak. Komik dalam kegiatan pembelajaran dapat digunakan untuk memotivasi, karena isinya berupa bentuk kartun yang efektif akan menarik perhatian serta akan menumbuhkan minat belajar siswa. Sardiman, dkk (2011) menyatakan bahwa kartun adalah suatu gambar interpretatif yang menggunakan simbol-simbol untuk menyampaikan suatu pesan secara cepat dan ringkas atau suatu sikap terhadap orang, situasi atau kejadian-kejadian tertentu.

Komik edukasi diberikan dengan sengaja agar pembaca menjadi dewasa atau mencapai tingkat hidup atau penghidupan yang lebih tinggi dalam arti mental sesuai dengan tujuan pendidikan. Ciri-ciri proses edukatif menurut Sardiman (2012), antara lain ada tujuan yang ingin dicapai, ada bahan/pesan yang menjadi interaksi, ada pelajar yang aktif mengalami, ada guru yang melaksanakan, ada metode untuk mencapai tujuan, ada situasi yang memungkinkan proses belajar mengajar berjalan dengan baik, dan ada penilaian terhadap hasil interaksi. Oleh karena itu, komik dikatakan edukatif bilamana mampu memenuhi kriteria yang dimaksud.

Peranan pokok dari komik edukasi adalah mampu dalam menciptakan minat para peserta didik. Melalui bimbingan guru, komik dapat berfungsi sebagai jembatan untuk menumbuhkan minat peserta didik terhadap pemberian bimbingan yang dilakukan. Kelebihan komik adalah gambar cerita (komik) memiliki unsur sederhana, jelas, mudah, dimengerti dan dapat menambah perbendaharaan kata para pembaca. Komik dapat mempermudah peserta didik menangkap hal-hal atau rumusan yang abstrak, Selanjutnya, apabila mendapatkan bimbingan dengan baik, maka komik dapat mengembangkan minat baca peserta didik dari suatu bidang pengetahuan. Selain itu, komik juga melatih daya imajinasi peserta didik sehingga sejalan dengan salah satu tujuan pendidikan yaitu agar kelak menjadi peserta didik yang kreatif.

\section{Simpulan}

Media bimbingan dan konseling yang diberikan harus memperhatikan karakteristik peserta didik/individu yang dituju. Subjek sasaran membawa konsekuensi tersendiri bagi guru BK, sehingga harus dapat menyesuaikan diri dengaan sasaran yang dituju. Peranan pokok dari komik edukasi adalah kemampuannya dalam menciptakan minat para peserta didik. Melalui bimbingan guru, komik dapat berfungsi sebagai jembatan untuk menumbuhkan minat peserta didik terhadap pemberian bimbingan yang dilakukan. Penggunaan komik edukasi yang dipadukan dengan layanan bimbingan dan konseling mengajar guru dapat menjadikan pelaksanaan layanan menjadi lebih baik.

\section{DAFTAR PUSTAKA}

Arsyad, A. (2011). Media pembelajaran. Jakarta: PT Raja grafindo persada.

Asyhar, R. (2012). Kreatif mengembangkan media pembelajaran. Jakarta: Referensi Jakarta.

Basri, A. S. H. (2010). Peran media dalam layanan bimbingan konseling Islam di sekolah. Jurnal Dakwah, 11(1), 23-41.

Beaulieu, D. (2004). Impact techniques in the classroom. Crown House Publishing.

Bonneff, M. (2008). Komik Indonesia. Kepustakaan Populer Gramedia.

Cho, H., \& Lawrence, D. G. (2012). Using of comics to increase interest and motivation. 12th International Congress on Mathematical Education, http://Www. Icme12.Org/Upload/ Upfile2/Wsg/0264. Pdf Diakses Pada, 14.

Daryanto, D. (2013). Media pembelajaran peranannya sangat penting dalam mencapai tujuan pembelajaran. Gava Media.

Departemen Pendidikan Nasional. (2008). Penataan pendidikan profesional konselor dan layanan bimbingan dan konseling dalam jalur pendidikan formal. Departemen Pendidikan Nasional. 
Gunarsa, S. D. (2008). Psikologi perkembangan anak dan remaja. BPK Gunung Mulia.

Hurlock, E. B. 2010. Psikologi perkembangan suatu pendekatan sepanjang rentang kehidupan (Alih Bahasa Istiwidayanti dkk. Edisi Kelima. Jakarta. Erlangga.

Radjah, C. L. (2016). Keterampilan konseling berbasis metakognisi. Jurnal Kajian Bimbingan dan Konseling, 1(3), 90-94.

Sardiman, A. M. (2000). Interaksi \& motivasi belajar mengajar. PT RajaGrafindo Persada.

Sardiman, A.S, dkk. (2011). Media pendidikan, pengertian, pengembangan dan pemanfaatannya. Jakarta. PT RajaGrafindo Persada.

Sardiman, A. M. (2012). The teaching of social studies in the global perspective. The Journal of Social Studies Education, 1(1).

Sukiman, S. (2012). Pengembangan media pembelajaran. Yogyakarta: Pedagogia: PT. Pustaka Insan Madani.

Wenda, Y. (2009). Media pembelajaran berbasis cetakan. Randa's Family Press.

Yusuf, L. N. S., \& Nurihsan, A. J. (2010). Landasan bimbingan dan konseling, Bandung, PT. Remaja Rosdakarya. 